Enraged or Engaged?

\title{
Preferences for Direct Citizen Participation in Affluent Democracies
}

\author{
Shaun Bowler \\ University of California, Riverside \\ Todd Donovan \\ Western Washington University, Bellingham \\ Jeffrey A. Karp \\ University of Exeter, United Kingdom
}

\begin{abstract}
Widespread approval of direct democracy has been attributed to politically engaged citizens who seek more opportunities to participate in politics. Others suggest that people prefer a limited role in politics, but cynicism with representation leads them to embrace direct democracy. The authors analyze opinion in sixteen affluent democracies to test these explanations. The authors find expectations of "more participation" were motivated by distrust of government and the belief that a citizen had a duty to keep a watch on government. Distrust, however, had an inverse relationship with approval of referendums in several nations. Support for referendums was greater among people who expect more opportunities to participate in public decisions and from people who were interested in politics, trusted government, and were satisfied with how democracy was working. Enthusiasm for direct democracy may reflect what people find lacking in representative democracy as much as it reflects interest in a more participatory version of democracy.
\end{abstract}

Keywords: direct democracy; referendum; distrust; public opinion

$\mathrm{O}$ pinion surveys from many advanced democracies repeatedly find widespread popular support for the institutions of direct democracy: the initiative and referendum (e.g., Dalton, Burklin, and Drummond 2001; Cronin 1989; see also Budge 1996; Norris 1999). There are, broadly speaking, at least two rival interpretations of these patterns. On one hand, popular approval of direct democracy can be interpreted as validating the Populists' faith in the willingness of politically engaged voters to govern themselves via a more direct, active role in policy making (e.g., Sullivan 1892; Haynes 1907; Beard and Schultz 1912). Others question whether enthusiasm for direct democracy reflects that citizens desire a more active role in their political process (e.g., Hibbing and Theiss-Morse 2001, 2002).

In this study, we examine public opinion across a range of affluent democracies to assess interpretations of the meaning of popular support for direct democracy. We test if approval of direct democracy is associated with the desire for greater direct participation or dissatisfaction with representative democracy. Our cross-national analysis demonstrates that support for having "more" opportunities to participate is motivated by distrust of government, as well as the belief that a citizen has a duty to keep a watch on their government. At the same time, specific approval of having people vote directly on policy flows from individuals who think democracy should provide people with more opportunities to participate and, in many places, from people who are more interested in politics and more trusting of government. The most consistent result in our cross-national findings, however, is that people who are suspicious of government expect more opportunities to participate. Overall, we find people support direct democracy to better control discretion delegated to their representatives.

\section{Popular Approval of Direct Democracy}

If results of opinion polls are to be taken at face value, most people surveyed in affluent democracies appear to demand, or at least approve of, direct citizen

Authors' Note: The authors contributed equally to the article and are listed in alphabetical order. 
Table 1

Public Attitudes on Direct Democracy in Sixteen Nations

\begin{tabular}{|c|c|c|c|c|c|c|c|c|c|c|c|c|c|c|c|c|}
\hline & US & AS & $\mathrm{AU}$ & CAN & $\mathrm{CZ}$ & FIN & GER & GB & NL & $\mathrm{NZ}$ & SP & SWI & HUN & SLA & SLO & LAT \\
\hline Strongly agree $(\%)$ & 12 & 44 & 15 & 19 & 26 & 18 & 35 & 19 & 16 & 22 & 27 & 22 & 10 & 16 & 19 & 19 \\
\hline Agree $(\%)$ & 52 & 37 & 48 & 47 & 38 & 37 & 46 & 48 & 50 & 49 & 51 & 62 & 30 & 40 & 27 & 43 \\
\hline $\begin{array}{l}\text { Neither agree } \\
\quad \text { nor disagree }(\%)\end{array}$ & 27 & 11 & 23 & 21 & 23 & 23 & 10 & 23 & 20 & 18 & 15 & 12 & 32 & 24 & 19 & 27 \\
\hline Disagree $(\%)$ & 8 & 6 & 11 & 11 & 10 & 17 & 7 & 8 & 11 & 8 & 6 & 4 & 20 & 15 & 18 & 8 \\
\hline Strongly disagree (\%) & 1 & 3 & 2 & 2 & 4 & 6 & 2 & 2 & 4 & 3 & 1 & 1 & 8 & 5 & 16 & 3 \\
\hline $\begin{array}{l}\text { Number of } \\
\text { respondents }\end{array}$ & 1,378 & 937 & 1,777 & 1,149 & 1,274 & 1,226 & 1,234 & 763 & 1,583 & 1,260 & 2,176 & 1,020 & 934 & 1,012 & 1,015 & 934 \\
\hline
\end{tabular}

Source: International Social Survey Programme (ISSP) Citizenship module, 2004.

Note: Respondents were asked, "Thinking about politics in [COUNTRY], to what extent do you agree or disagree: Referendums are a good way to decide important political questions?" Countries include Austria (AS), Australia (AU), Canada (CAN), the Czech Republic (CZ), Finland (FIN), Germany (GER), Great Britain (GB), Hungary (HUN), Latvia (LAT), the Netherlands (NL), New Zealand (NZ), Spain (SP), Slovakia (SLA), Slovenia (SLO), Switzerland (SWI), and the United States (US).

influence over policy decisions (Dyck and Baldassare 2006). A survey conducted in 2003 found more than 70 percent of American respondents supporting a proposal for a national initiative and referendum process (Bowler and Donovan forthcoming), and similar levels of support were found in the 1980s (Cronin 1989). Polls conducted in California since the late 1990s consistently put popular support of ballot measures at around 65 to 70 percent. ${ }^{1}$ Likewise, a 1997 Eurobarometer poll found 72 percent of British respondents favored having a "Swiss" form of direct democracy, with even higher levels of support for the Swiss system found in Austria, Greece, Germany, Ireland, Portugal, and Belgium. A 1998 German Election Study found that more Germans favored principles of direct democracy than favored principles of representative democracy (Dalton, Burklin, and Drummond 2001).

We measured approval of direct democracy across sixteen affluent democracies with questions placed on the International Social Survey Programme (ISSP) 2004 Citizenship module. Respondents in each nation were asked, "Thinking now about politics in [NATION], to what extent do you agree or disagree that referendums are a good way to decide important political questions?" As Table 1 illustrates, there is substantial approval of the use of referendums across these sixteen democracies. ${ }^{2}$ The highest level of approval is in Switzerland, the nation with the greatest use of direct democracy. A majority of respondents in every nation but Hungary and Slovenia agree that referendums are a good way to decide important issues. ${ }^{3}$

Substantial proportions of citizens in each of these nations thus have positive views of direct democracy, including nations where referendums have occasionally played a prominent role in national politics (e.g., Australia, Canada, Spain, Switzerland). In contrast, relatively few offer negative assessments; rather, those who are not positive about referendum use appear largely ambivalent (e.g., Hungary). It is important to note that referendums are used in each of these nations, but the process is employed differently in each place. In most of these nations, citizen-initiated referendums are not used, but national constitutional referendums have been used in Australia and Canada. ${ }^{4}$ Citizens in Austria, the Czech Republic, Finland, Hungary, Latvia, the Netherlands, Slovakia, Slovenia, and Spain have voted on measures affecting relations with the EU and/or NATO. Some nations (Great Britain, Hungary, Spain) have also made infrequent use of regional or national referendums on other topics. In New Zealand, a few nonbinding citizen-initiated measures were voted on nationally in the 1990s. ${ }^{5}$ Citizen-initiated referendums play a major role in Swiss politics and are used in several American states and some German Länder. Despite such contextual differences across these places, solid majorities of respondents in most settings agreed that direct citizen participation in policy making was a good thing.

What do these seemingly high levels of support for direct democracy actually mean, and what does it say about whether public interest in direct democracy may or may not reflect a desire to expand opportunities for citizens to participate in democratic societies? We begin to answer these questions by examining explanations of who supports direct democracy. Following this, we incorporate a more nuanced interpretation of people's expectations about how democracy should work.

These high levels of popular support for direct involvement in politics are, in some ways, puzzling. 
There is evidence that the public dislikes the workings of democratic institutions (Hibbing and TheissMorse 1995) and that they have a distaste for further participation in politics (Hibbing and Theiss-Morse 2001). Many people also lack a substantive base of factual information about politics (Delli Carpini and Keeter 1996). Nonetheless, although people may have very little desire to take an active role in policy making, they may feel the need to because they do not trust elected officials to act properly. Or as Hibbing and Theiss-Morse $(2002,227)$ noted, their "sourness toward government does not stem from the fact that they want to be more involved, but from the fact that they feel as though they need to be involved even though they would rather not be." Cronin (1989) also noted that most citizens like direct democracy but do not want to take over decision making from elected officials.

\section{The Contested Meaning of Popular Interest in Direct Democracy}

It is not clear what widespread support for direct democracy actually tells us about citizen preferences for democratic practices. When support for direct democracy is considered in light of the classic trustee model of representation, it makes little sense. A trustee model (Burke 1774/1854) is based on the idea that people have neither the taste nor the capacity for participation in governing. Widespread interest in direct democracy may fit better with delegate or populist models of representation if public approval of using direct legislation actually reflects genuine citizen engagement in politics and a corresponding desire to broaden and deepen the institutions of democracy.

Populism, at least the American version, can be seen as a variant of the delegate model of representation. American Populists promoted direct democracy in an era when many state legislatures were notoriously corrupt and unresponsive to major social and economic changes (see Piott 2003). Populists viewed direct democracy as an institutional tool that could be used to force legislatures to better respond to mass preferences for policies (Johnson 1944). Other arguments explaining demands for more democracy come from studies of Europe and other nations, where contemporary attitudes about the role of a citizen may reflect demographic and "values" changes have led to greater mass support for direct citizen influence over policy. Rising affluence may cause people to expect a greater direct role in governing, as postmaterial values spread (Inglehart 1977, 1991) and as "critical citizens" become more educated and media-savvy (Budge 1996; Norris 1999).

Unfortunately, these explanations do not provide much empirical evidence of links between support for direct democracy and citizen assessments of how democracy is working (or should be working). Rather, the meaning of popular expectations for more participation, and support for direct legislation, are adduced from the claims of direct democracy's supporters or from general demographic or values shifts at a societal level. Questions about the meaning of popular interest in direct democracy thus remain unanswered.

Historically, the introduction of direct democracy was associated with a profound dissatisfaction with the performance of representative institutions (Hicks 1931; Hofstadter 1955; Cain and Miller 2001; Piott 2003). This suggests there are limits to the public's willingness to delegate full control of policy to representatives. If views of direct democracy are tied to views of representative democracy, what people may wish to delegate to legislators may well depend both on how they view the representativeness of their government and their party system. Citizens may, quite simply, be prepared to grant representatives more of a trustee role if they see representative institutions performing well and may be more willing to restrict the discretion of representatives via direct democracy when they believe representative institutions are behaving poorly. People disenchanted with the performance of traditional representative institutions may thus be expected to be more enthusiastic about direct democracy (LeDuc 2003, 30).

To the extent that there is any systematic basis to popular approval of direct democracy, and to expectations for having "more" democracy, it is likely driven by evaluations of politics and political process concerns, especially by evaluations of how democracy should work (Hibbing and Theiss-Morse 2002) and by perceptions of what a citizen's proper role is in a democratic society.

\section{Modeling Public Expectations of More Democracy}

There is little published research that tests specific hypotheses about who supports direct democracy. ${ }^{6}$ Dalton, Burklin, and Drummond $(2001,145)$ provide one of the few attempts at generating systematic hypotheses about what they see as a shift in the European electorate toward greater enthusiasm for direct democracy. They 
offer two broad explanations that have different implications for our understanding of what support for direct democracy actually reflects (also see Craig, Kreppel, and Kane 2001). The "new politics" explanation is largely derived from the work of Dalton (1984) and Inglehart $(1977,1991)$, and holds that direct democracy is most valued by citizens with new democratic values, who are more engaged with politics. They also advance a rival "political disaffection" hypothesis, which "argues that unease with the way representative democracy currently functions ... may be stimulating support for direct democracy as an alternative" (Dalton, Burklin, and Drummond 2001, 145).

The first of these explanations is based on the idea that many citizens in established democracies now hold postmaterialist values that reflect a retreat from hierarchy and include a desire for a more participatory role in politics (Dalton, Burklin, and Drummond 2001, 146). This leads one to expect politically engaged citizens to be more supportive of direct democracy. ${ }^{7}$ Donovan and Karp (2006) find some support for this hypothesis in an analysis of attitudes toward direct democracy in six countries; younger citizens and those more interested in the political process were more supportive of direct democracy. Some (Budge 1996; Norris 1999) also link approval of greater democracy to education and assume that highly educated, "critical" citizens will see more need for direct democracy than other people. From this perspective, better educated citizens may also be more likely to want to expand opportunities to participate in politics since they are more likely to have the skills and resources needed to navigate policy decisions placed on ballots. In our analysis we rely on political interest, education, frequency of political discussion, and a measure of social group membership (a marker for social capital) to identify people whom we expect to be most engaged with politics.

The political disaffection explanation would find support if approval of direct democracy is greater among people who are relatively angry about the representativeness of their government and the choices presented by political parties. Disaffection is measured here with a standard "trust in government" question, and with attitudes about whether "government cares much what people like me think." ${ }^{8}$ We account for disaffection with the party system using a question asking respondents whether they agree that "political parties do not give voters real policy choices." "We also include a measure of personal efficacy to further test the disaffection explanation (using responses to a "people like me have no say" question).
The literature suggests other explanations of support for direct democracy, including a hybrid of these two explanations. As noted above, evaluations of the overall performance of a nation's democracy could affect attitudes about increasing citizen influence over policy making. Our models include a measure where people rank, on a scale of 0 (very poor) to 10 (very well), how well they think democracy is working in their nation. The disaffection explanation suggests that negative assessments of a nation's democratic performance may increase interest in additional opportunities for direct citizen participation.

Hibbing and Theiss-Morse's research (2002) may also be read as offering what we call a "disaffected critical citizen" explanation of why people might expect more direct citizen input. From this perspective, people may be suspicious of public officials to the point they feel vigilant citizens must keep watch on what government is doingbut they may not want to be more active in politics. The ISSP allows us to estimate if support for direct democracy is greater among people who feel that it is important for citizens to keep watch on government-independent of their level of political interest and expectations for more opportunities to participate. ${ }^{10}$ The models also control for age and gender. Given low levels of political representation of women, we anticipate that women are more likely to expect additional modes of democratic participation.

In addition to modeling approval of direct voting on policy, we also consider attitudes about having more prospects for participation generally. The ISSP Citizenship module included a question asking how important it is in a democracy "that people be given more opportunities to participate in public decision making." It is important to note that this attitude is somewhat distinct from approval of using referendums, and these two questions were placed far from each other in the survey. Responses to the two questions are only weakly correlated $(r=.14$ in the United States and -.07 at the aggregate level). However, if widespread approval of direct democracy reflects mass preferences for increasing the opportunities people have to participate in politics, then expectations of greater participation should be related to approval of referendums. Given that these attitudes are only modestly correlated with each other, expectations of greater opportunities for participation may also have roots that are unique from those driving support for direct democracy. That is, disaffection or political engagement may lead to expectations for more direct citizen participation, but these forces need not have the same effects on support for using referendums. 
Table 2

Estimates of Expectations of More Opportunities to Participate, and Approval of Referendum Use (United States)

\begin{tabular}{|c|c|c|c|}
\hline \multirow[b]{2}{*}{ Important to have more opportunities to participate } & \multirow{2}{*}{$\begin{array}{c}\text { More Opportunities } \\
\text { to Participate? } \\
\text { (7-Point Scale) } \\
-\end{array}$} & \multicolumn{2}{|c|}{$\begin{array}{l}\text { Referendums a Good } \\
\text { Way to Decide Policy } \\
\text { (5-Point Scale) }\end{array}$} \\
\hline & & $\overline{(.02)}$ & $.09^{* *}$ \\
\hline \multicolumn{4}{|l|}{ Disaffection } \\
\hline Distrust government (5-point scale) & $\begin{array}{l}.07 * \\
(.03)\end{array}$ & $\begin{array}{c}-.05^{*} \\
(.02)\end{array}$ & $\begin{array}{c}-.05^{*} \\
(.02)\end{array}$ \\
\hline Government doesn't care (5-point scale) & $\begin{array}{c}.07 * \\
(.03)\end{array}$ & $\begin{array}{c}.03 \\
(.02)\end{array}$ & $\begin{array}{c}.02 \\
(.02)\end{array}$ \\
\hline Respondent has no say (5-point scale) & $\begin{array}{c}-.01 \\
(.03)\end{array}$ & $\begin{array}{c}-.03 \\
(.02)\end{array}$ & $\begin{array}{c}-.03 \\
(.02)\end{array}$ \\
\hline Satisfied with how democracy working (10-point scale) & $\begin{array}{l}.04 * \\
(.01)\end{array}$ & $\begin{array}{c}.001 \\
(.01)\end{array}$ & $\begin{array}{c}-.002 \\
(.01)\end{array}$ \\
\hline Parties offer no policy choices (5-point scale) & $\begin{array}{c}.07^{*} \\
(.03)\end{array}$ & $\begin{array}{l}.01 \\
(.02)\end{array}$ & $\begin{array}{c}-.002 \\
.02)\end{array}$ \\
\hline Important that citizens keep watch on government (7-point scale) & $\begin{array}{l}.20^{*} \\
(.03)\end{array}$ & $\begin{array}{l}.04 * * \\
(.02)\end{array}$ & $\begin{array}{l}.02 \\
(.02)\end{array}$ \\
\hline \multicolumn{4}{|l|}{ Engaged citizens } \\
\hline Interested in politics (4-point scale) & $\begin{array}{c}.06 * \\
. .04)\end{array}$ & $\begin{array}{l}. .07 * * \\
(.03)\end{array}$ & $\begin{array}{c}.06 * \\
\text { (.03) }\end{array}$ \\
\hline Discuss politics (4-point scale) & $\begin{array}{l}.02 \\
(.03)\end{array}$ & $\begin{array}{c}-.01 \\
(.02)\end{array}$ & $\begin{array}{l}-.01 \\
(.02)\end{array}$ \\
\hline Education (years) & $\begin{array}{c}-.04 * \\
(.01)\end{array}$ & $\begin{array}{l}-.008 \\
(.009)\end{array}$ & $\begin{array}{l}-.003 \\
(.008)\end{array}$ \\
\hline Social group member $(1 / 0)$ & $\begin{array}{c}-.02 \\
(.07)\end{array}$ & $\begin{array}{l}. \mathbf{1 1} * * \\
(.05)\end{array}$ & $\begin{array}{l}.11^{*} \\
(.05)\end{array}$ \\
\hline Age (years) & $\begin{array}{c}.001 \\
(.001)\end{array}$ & $\begin{array}{l}.005 * * \\
(.001)\end{array}$ & $\begin{array}{l}. \mathbf{. 0 0 5}^{* *} \\
(.001)\end{array}$ \\
\hline Female (1/0) & $\begin{array}{l}.20 * \\
(.06)\end{array}$ & $\begin{array}{c}-.01 \\
(.04)\end{array}$ & $\begin{array}{l}-.02 \\
(.04)\end{array}$ \\
\hline Constant & 5.3 & -2.4 & -3.0 \\
\hline Number of cases & 1,399 & 1,342 & 1,338 \\
\hline Adjusted $R^{2}$ & .08 & .02 & .04 \\
\hline
\end{tabular}

Source: International Social Survey Programme (ISSP) 2004 Citizenship Module.

Note: Coefficients in bold are statistically significant.

*Significant at $p<.10 . * *$ Significant at $p<.05$.

\section{Findings}

We proceed by estimating two sets of models that are based on the following questions: "How important is it that people be given more opportunities to participate?" and "Are referendums a good way to decide important political questions?" These items form 7- and 5-point scales, respectively; therefore we use ordinary least squares (OLS) to estimate the models. ${ }^{11}$ To ease the presentation of the results, we first report the estimates for the United States in Table 2. We then summarize the results across all sixteen nations in Table 3, listing for each variable those nations where the variable had a significant (positive or negative) effect on responses to these two questions (full estimates for each nation are reported in an online appendix ${ }^{12}$ ). Our goal here is not to explain why certain factors might affect opinions about participation and direct democracy differently across these countries. Rather, we employ cross-national data to assess how far we might be able to generalize about the sources of such opinions in affluent democratic societies.

\section{Factors Affecting Expectations for More Public Participation in Decision Making}

Table 2 displays estimates of factors affecting expectations for more opportunities for citizen participation. Here 
Table 3

Factors Affecting Importance Placed on Having More Opportunities to Participate, and Approval of Referendum Use (and direction of relationship).

\begin{tabular}{|c|c|c|}
\hline & More Opportunities to Participate? & Referendums a Good Way to Decide Policy? \\
\hline Important to have more opportunities & $\rightarrow$ & $\begin{array}{l}\text { Positive: AU, AS, CAN, CZ, FIN, GER, } \\
\text { GB, HU, LAT, NL, NZ, SLA, SLO, SP, US }\end{array}$ \\
\hline \multicolumn{3}{|l|}{ Disaffection } \\
\hline Distrust government & $\begin{array}{l}\text { Positive: AU, CAN, FIN, HU, NL, } \\
\text { NZ, SLA, SLO, US }\end{array}$ & Negative: AU, CAN, SLO, SP, SWI, US \\
\hline Government doesn't care & $\begin{array}{l}\text { Positive: AU, AS, CAN, CZ, FIN, } \\
\text { GER, SLO, SWI, US }\end{array}$ & Positive: FIN, GER, HUN, NL, SWI \\
\hline People like me have no say & Positive: GB & Positive: CAN, GER, SPA; Negative: SWI \\
\hline Satisfied with democracy & $\begin{array}{l}\text { Positive: NL, US; Negative: GER, GB } \\
\text { Negative: FIN }\end{array}$ & Positive: AU, GB, SLA, SLO, SP, SWI; \\
\hline Parties offer no policy choices & $\begin{array}{l}\text { Positive: CAN, LAT, NZ, US } \\
\text { LAT, NL, NZ, SLA, SP }\end{array}$ & Positive: AS, CAN, FIN, GER, GB, HUN, \\
\hline $\begin{array}{l}\text { Important that citizens keep } \\
\text { watch on government }\end{array}$ & $\begin{array}{l}\text { Positive: AU, AS, CAN, CZ, GER, GB, } \\
\text { HUN, NL, NZ, SLA, SLO, SP, SWI, US }\end{array}$ & Positive: AU, AS, HUN, SLA, SLO, SWI \\
\hline \multicolumn{3}{|l|}{ Engaged citizens } \\
\hline Interested in politics & $\begin{array}{l}\text { Positive: AS, CAN, CZ, LAT, SLA, US; } \\
\text { Negative: SWI }\end{array}$ & Positive: CZ, GER, LAT, SLA, SP, US \\
\hline Discuss politics & Positive: CAN, CZ, NL, SP & Positive: AS, CZ, SP, SWI; Negative: SLO \\
\hline Education & Negative: CAN, FIN, GB, SLA, SP, SWI, US & Negative: CAN, FIN, GER \\
\hline Social group member & $\begin{array}{l}\text { Positive: CZ, GER; Negative: AU } \\
\text { Negative: HUN, SLO }\end{array}$ & Positive: AS, CZ, SP, SLA, US; \\
\hline
\end{tabular}

Note: Countries include Austria (AS), Australia (AU), Canada (CAN), the Czech Republic (CZ), Finland (FIN), Germany (GER), Great Britain (GB), Hungary (HUN), Latvia (LAT), the Netherlands (NL), New Zealand (NZ), Spain (SP), Slovakia (SLA), Slovenia (SLO), Switzerland (SWI), and the United States (US).

we find some consistent support for the political disaffection explanation. In the United States, people who distrust government, those who think government does not care about people like themselves, and people who are dissatisfied with choices that parties offer are, independently, significantly more likely to expect that democracy should provide more opportunities to participate in public decisions.

Table 3 illustrates that these effects are not unique to the United States. Distrusting Australians, Canadians, Finns, Hungarians, Dutch, New Zealanders, Slovakians, and Slovenians are all significantly more likely to expect democracy to provide people more opportunities to participate. The relationship between perceptions that government does not care and preferences for more participatory opportunities is significant in a majority of the sixteen nations we examine. Disaffection with the policy choices that parties present also corresponds with preferences for more opportunities to participate in Canada, Latvia, and New Zealand.

But we also find results that are inconsistent with the disaffection explanation, and some results support the idea that politically engaged citizens expect additional opportunities for political participation. Interested citizens in the United States, Austria, Canada, the Czech Republic, Latvia, and Slovakia are significantly more likely to expect that democracy should provide people more opportunities to participate. The only case where the direction of this relationship is reversed is Switzerland, where expectations for more opportunities come from the least interested. This may reflect the unique context of Switzerland, where the existing, expansive use of direct democracy may act to incorporate the politically interested more so than in other nations.

There are other scattered results that also contradict the disaffection hypothesis and appear more consistent with the idea that politically engaged citizens expect more opportunities to participate. Americans (and Dutch) who rate democracy as working very well are significantly more likely to expect that democracy provide further opportunities for direct participation. In four nations, people who discuss politics most frequently were significantly more likely to have this opinion. However, contrary to what we expected from the engaged citizens hypothesis, Americans with less formal education are more likely to say that democracy should provide additional opportunities for participation. We find the same result in 
five other nations. In most nations, women are significantly more likely to say that democracy should provide further opportunities for political participation.

\section{Factors Affecting Approval of Referendum Use}

The second and third columns in Table 2 assess which attitudes are associated with approval of using referendums to decide important matters of policy. Table 3 illustrates that the most consistent factor predicting preferences for direct voting on policy is the expectation that democracy should provide people with more opportunities to participate. In fifteen of the sixteen nations, this attitude has the largest substantive relationship with approval of direct democracy. Among Americans, a shift from the low to high end of the 7point "more opportunities to participate" attitude scale corresponds with a .67 deviation increase on the "referendums are a good way to decide policy" attitude. $^{13}$ In every nation examined here but Switzerland, those who rate it very important that democracy offer people additional opportunities to participate were significantly more likely to approve of direct democracy. Again, the null finding for Switzerland may reflect the unique, active experience the Swiss have with direct democracy. Only 27 percent of Swiss respondents reported it was important for democracy to provide more opportunities to participate. In contrast, this sentiment was shared by 40 percent-60 percent of respondents from the other fifteen nations, where direct democracy plays a less important role in political life.

The results in Table 2 also demonstrate that although distrust of government, low efficacy, frustration with parties, and low education each have independent effects associated with the general expectation of greater citizen participation, none of these factors are associated with greater interest in direct democracy (referendum use) in the United States. ${ }^{14}$ Table 3 illustrates that across these sixteen nations, some of these measures of political disaffection (low trust and low efficacy) have a much less systematic relationship with approval of direct voting on policy than do expectations that people need "more opportunities" to participate. Likewise, the effect for gender (see the online appendix) demonstrates that in most of these nations women, more than men, expect more opportunities to participate; with the exception of Austria, however, women are not more enthusiastic about having the public vote directly on matters of policy.
In most of these nations, some factors that are consistently associated with general expectations for more opportunities to participate-particularly political disaffection and gender-do not often correspond with specific approval of using referendums. Although the disaffection explanation for interest in direct democracy appears to have limited explanatory power in the United States and most of these nations, there is stronger support for it in a few cases-most consistently in Germany and Finland. Furthermore, in most nations people who are cynical about the policy choices offered by political parties are significantly more supportive of direct democracy. This finding is consistent with the idea that interest in direct democracy reflects political disaffection.

That said, in the United States, Australia, Canada, Slovenia, Spain, and Switzerland, those who trust government are actually more enthusiastic about using referendums. Table 2 illustrates that this effect is robust across different model specifications. ${ }^{15}$ In several nations, people most satisfied with how democracy is working, and those most interested in politics, are also significantly more likely to support using referendums to decide important matters of policy. Americans who are members of social groups, and those who are more interested in politics, are also significantly more likely to approve of direct democracy. These patterns are consistent with the idea that widespread approval of direct democracy displayed in Table 1 reflects the preferences of politically engaged citizens, as much as or more than it reflects a vision of democracy preferred largely by the politically disaffected.

\section{The Importance of Keeping Watch on Government}

One of our most consistent results supports the hypothesis derived from Hibbing and Theiss-Morse (2002). In fifteen of sixteen nations, people who believed it was important for citizens to "keep watch on the actions of government" were significantly more likely to expect democracy to offer people more opportunities to participate. That is, independent of a person's level of engagement or disaffection, those who believe that good citizens must keep watch over their government are substantially more likely to expect additional opportunities to affect public decisions. This is the largest substantive component of the models estimated in Table 2 and in the online appendix. Among Americans, for example, a shift from the low to high end of the 7-point "keep watch" attitude scale corresponds with a one standard deviation 
increase on the "more opportunities to participate" measure. ${ }^{16}$ When the model in the first column of Table 2 is estimated without the "keep watch" attitude (not reported here), the relationship between political interest and expectations of more opportunities to participate is much more pronounced. This suggests that the "keep watch" attitude is capturing some of the effects of political interest. The "keep watch" attitude and political interest are modestly correlated at $r=.24$.

As Table 3 summarizes, in six nations the relationship between the "keep watch" attitude and approval of direct democracy persists when models account for attitudes about the need for more participation. In these nations, results suggest that people who think it is important to watch government attach more importance to having more chances for participation generally and to using referendums specifically. However, as much as the "keep watch" attitude predicts who expects "more opportunities to participate" across fifteen of sixteen nations, it is less powerful explaining who approves of using referendums. In the United States and most other nations, the relationship between the "keep watch" attitude and support for using referendums disappears when we account for attitudes about more opportunities to participate. This can be seen by comparing estimates in column 2 of Table 2 to those in column 3 .

Put differently, the idea that a good citizen must keep a vigilant eye on government increases expectations of more opportunities to participate (first column, Table 2). This, in turn, may increase interest in using direct democracy (second column, Table 2). Yet when attitudes about a general need for more opportunities to participate-attitudes associated with disaffection-are used to model approval of direct democracy (third column, Table 2), this relationship between "keep watch" and approval of referendum use dissipates. Our goal here is not to develop and test a full causal model of how these attitudes affect interest in direct citizen participation. However, these results suggest a pattern where political interest and political disaffection may lead people to place greater value on having citizens keep watch on their government. This, in turn, may increase interest in direct democracy indirectly, by increasing the likelihood that a person thinks there should be more opportunities to participate in public decisions.

It is not clear from this that people feel the need to be more involved with politics. But in several nations, political interest-which we assume to reflect engagement with politics-does predict expectations for more opportunities for participation. Approval of direct democracy in the United States appears to be wrapped up in popular expectations for more opportunities, independent of the effects of suspicion about government and political disaffection. In many of these nations we find that directly or indirectly, expectations of more opportunities to participate (generally) and approval of using direct democracy (specifically) are affected by the idea that citizens must keep watch on their government. These survey questions do not allow us to assess if (or when) people might take advantage of such opportunities. If we assume people are as interested in the existence of more opportunities to express themselves as much as they actually do so, these assumptions are consistent with a delegate model of representation. Distrust of government, cynicism, perceptions that citizens must be vigilant, frustration with parties, and political interest drive people to expect more opportunities for input into their political system. This, in turn, may lead them to support the idea of the public retaining the ability to occasionally exercise a veto over important matters of public policy.

\section{Perceptions of "Special Interest" Influence and Support for Direct Democracy}

The ISSP data are not well suited for assessing if citizen expectations about democratic arrangements extend beyond a delegate model of representation, to a more fully populist (or participatory) model of democracy. We approach this question by examining public opinion about direct democracy in California. The Californian case merits attention, as Californians have more experience with direct democracy than citizens anywhere in the world (other than residents of Oregon, or Switzerland, perhaps). Moreover, after decades of initiative use that some link to the state's enduring fiscal problems (e.g., Schrag 2004), and after a contentious recall of a sitting governor, a majority of Californians continued to approve of direct democracy. ${ }^{17}$ California thus proves fertile ground for assessing attitudes about direct democracy and for investigating what it means for citizens to express support for such democratic arrangements.

Opinions described in Table 4 offer some perspective on how much approval of direct democracy can be interpreted as reflecting a fully populist view of democracy. Two-thirds of respondents to this 1999 California poll rated "ballot proposition elections" as 
Table 4

Comparisons of Representative and Direct Democracy (California)

\begin{tabular}{lcc}
\hline & $\begin{array}{c}\text { Elected } \\
\text { Representatives (\%) }\end{array}$ & $\begin{array}{c}\text { Voting } \\
\text { Public }(\%)\end{array}$ \\
\hline $\begin{array}{l}\text { Who enacts more } \\
\text { coherent policies? }(n=882)\end{array}$ & 61.3 & 38.7 \\
$\begin{array}{l}\text { Who is better suited to decide } \\
\text { legal policy? }(n=885)\end{array}$ & 73.0 & 27.0 \\
$\begin{array}{l}\text { Who is more thorough reviewing } \\
\text { proposed law? }(n=884)\end{array}$ & 68.3 & 31.7 \\
$\begin{array}{l}\text { Who is more influenced by } \\
\text { special interests? }(n=861)\end{array}$ & 77.0 & 23.0 \\
$\begin{array}{l}\text { Who is more often trusted to do } \\
\text { what is right? }(n=861)\end{array}$ & 31.4 & 68.6 \\
$\begin{array}{l}\text { Who considers broad public } \\
\text { interest more? }(n=819)\end{array}$ & 34.3 & 65.7 \\
\hline
\end{tabular}

Source: Field/California Poll 9902 (1999).

good things. Yet data in Table 4 illustrate that many Californians see faults with both direct democracy and representative government when asked to compare between the two. For all their enthusiasm about direct democracy, Californians also had a large measure of respect for their elected representatives. Majorities agreed that representatives gave laws a more thorough review than voters did, that representatives were better suited to decide "legal policy" than voters were, and that elected representatives enacted more "coherent" policies than voters. However, far more people trusted the voting public (rather than elected officials) "to do what is right" more often. Thus, we see high levels of public regard for major elements of representative democracy coexisting with high levels of approval of direct democracy.

The Field Poll also asked Californians about the nature of policy outcomes that result from representative and direct democracy processes. One question asked if outcomes from the legislature reflect what "most people" want or what "special interests" want. The second question asked the same about outcomes of ballot proposition elections. Forty-six percent of Californians, having great experience with direct democracy, agreed that outcomes of direct democracy reflect what "special interests" want and not what "most people" want. It seems, then, that many people are suspicious of the prospects of direct democracy. Not only are they likely to fear that voters may be unable to make distinctions about fine points of law and policy, but they also believe that voters (themselves) can fall prey to "special interests." But if so many Californians share this view of
Table 5

Attitudes about Direct Democracy and Governmental Responsiveness

\begin{tabular}{lcc}
\hline & \multicolumn{2}{c}{$\begin{array}{c}\text { Opinion of Ballot } \\
\text { Proposition Elections }\end{array}$} \\
\cline { 2 - 3 } & $\begin{array}{c}\text { No Difference; } \\
\text { Neither Good } \\
\text { Nor Bad }\end{array}$ & Good Thing \\
\hline $\begin{array}{l}\text { Proposition elections effects on government } \\
\text { No difference/ } \\
\text { less responsive }\end{array}$ & $71 \%$ & $23 \%$ \\
$\begin{array}{l}\text { Make government } \\
\text { more responsive }\end{array}$ & $(216)$ & $(143)$ \\
Total & $(88)$ & $77 \%$ \\
\hline
\end{tabular}

Source: Field/California Poll 9902 (1999).

Note: Chi-square $=196.7(p<.000)$.

direct democracy, why then do we find such high levels of approval of direct democracy there?

We suggest that the answer to this question may be that many citizens are attached to a delegate model of representation more than a fully participatory view of democracy, and they see direct democracy not as a method to govern by but as a means to better instruct their representatives. This view is consistent with the argument derived from Hibbing and Theiss-Morse (2002) proposing that support for direct democracy is rooted in evaluations of how representative government is working (or, more accurately, failing to work). Californians are leery of interest group influence in both the direct democracy and legislative arenas, but they see the legislative arena as being least likely to reflect "what most people want." Two-thirds of California respondents agreed that "special interests" dominate the decisions of their legislature-many more than share this view of direct democracy. Crosstabulating responses to the two questions illustrates that a plurality of respondents (37 percent) said that outcomes from both direct and representative democracy tended to reflect special interests, rather than "what most people want." However, Table 4 illustrates that 77 percent said representatives were more influenced by special interests than the voting public was.

Table 5 provides further evidence of how public approval of direct democracy is consistent with a delegate model of representation. Given that direct democracy limits discretion granted to representatives, we expect citizens who see direct democracy as a means for making policy more representative of 
public preferences to be more likely to approve of direct voting on public policy. The California poll asked respondents if ballot proposition elections made state government more responsive to the public or if they made no difference (or made government less responsive). More than 60 percent replied that direct democracy made state government more responsive, and 33 percent said it made no difference. When these attitudes are cross-tabulated with assessments of whether direct democracy is a good thing, we find the attitudes are highly correlated. Seventy-seven percent of respondents who said ballot measures were a good thing also agreed that they made their state government more responsive. Likewise, a large majority of those who were unimpressed with direct democracy believed it had no effect (or an ill effect) on making government more responsive to the public.

To summarize, we find most Californians do not think that the voting public is well suited to create highquality legislation, but they approve of direct democracy as a means to make elected officials more attentive to public opinion. This result from California echoes the important effect we find for the "keep watch on government" attitude in the cross-national data.

\section{Discussion}

Some have suggested that mass support for direct democracy reflects a desire for "more" democracy and for fewer intermediaries between the public and government. Others note that support for direct democracy need not mean that people seek more involvement with democratic politics. We find that public expectations for more opportunities to participate in public decision making, and widespread public approval of direct citizen voting on policy decisions are often closely linked. We also find some evidence that approval of direct democracy comes from the politically engaged, as much as, if not more than, it comes from people who are politically disaffected or angry about how democracy is currently working.

However, these results probably say more about what people find lacking in the performance of representative democracy than they reflect demands for a fully participatory version of democracy. Although we do find that expectations for more opportunities to participate are associated with greater support for using direct democracy, our results also demonstrate that the most consistent factors predicting interest in additional opportunities to participate are political distrust and the idea that citizens must "keep watch" on their government. We also find that approval of direct democracy in California corresponds with lukewarm assessments of the capacity of voters to govern themselves, but that it is highly correlated with the idea that direct democracy makes representatives more responsive to the public.

All of this suggests that many people view direct democracy as a means to make elected officials more representative to "the people" and less influenced by "special interests." Although definitions of the meaning that survey respondents attach to these concepts are problematic, on balance more people are worried about the influence that special interests (however defined) have over elected representatives than about special interest influence over the voting public. Our evidence demonstrates that citizens see participation via direct democracy as a check on government generally (in our cross-national data) and a check on the power that narrow interests have over representatives (in the California data).

How, then, might we interpret public cynicism about the influence of special interests and the importance that citizens in most nations attach to the need to keep watch on government? Public cynicism identified here seems somewhat sophisticated given the volume of theory and scholarship demonstrating that narrow economic interests thrive in arenas where rules limit the scope of conflict and the number of actors making decisions (e.g., Schattschneider 1960; Olson 1964; Lowi 1969). Empirical research also demonstrates that narrow interests usually fail to pass measures they put on statewide ballots (Gerber 1999, 111). The U.S. Supreme Court struck down campaign finance regulations on ballot measure campaigns using a logic similar to what we find here in the mass public. In its 1978 Bellotti decision, it ruled that "the risk of corruption" it perceived "involving candidate elections is not present in a popular vote on a public issue." Many citizens seem to reason in a manner similar to prominent jurists and political scientists: they assume that economic interests-business groups, professional associations, powerful corporations, labor unions-have more success when lobbying for narrowly tailored benefits from elected officials than when asking for them directly from the voting public. ${ }^{18}$ In addition, mass perceptions that direct democracy also makes government more responsive appear sophisticated given that theoretical and empirical scholarship documents that the initiative process can cause public policies to better reflect mass opinion for policies (Gerber 1999; Matsusaka 2004).

It is unlikely that people feel their vote for elected officials provides them much influence over policy if they believe their representatives' decisions often 
benefit "special interests" over what they think most people want. In contrast, if people see outcomes of initiatives and referendums as more likely to reflect their perceptions of what most people want, and they believed that direct democracy makes government more responsive, then direct democracy may be where they think they have a meaningful say in politics.

Putting these ideas a bit differently, a poll found that two-thirds of Americans agreed that corporations and the wealthy "had [recently] gained influence on the U.S. government." Eighty percent said the nation would be better off if leaders followed the views of the public more closely, and more than 80 percent agreed that people should have "more say." As Hibbing and Theiss-Morse (2002) noted, this does not mean people want to spend more time involved with politics. Rather, they want the same amount of time to yield dividends they have confidence in. The same poll cited above finding widespread interest in having "more say" also found two-thirds of Americans agreeing that representatives should pay attention to public opinion polls when they vote. Many people seem to look at direct voting on public policy as a tool for making delegates in the legislature adhere more closely to constituents' preferences.

\section{Notes}

1. See Field California Polls 1996-2004, 1997-2003, 1999-2002. A 2004 California/Field Poll found 68 percent saying ballot proposition elections were "good things"- - a slight increase from 1999.

2. The International Social Survey Programme (ISSP) 2004 Citizenship Module was conducted in thirty-four nations. Our case selection was driven by a goal of utilizing a set of nations that were established, affluent democracies with some practice using direct democracy. This eliminated several less affluent nations in the ISSP sample (e.g., Bulgaria, Mexico, Russia, Venezuela, Poland, South Africa, Philippines). Some nations with available data had limited experience with direct democracy (e.g., Japan, South Korea, Taiwan). At the time of our writing, data were not available from France, Ireland, Italy, Portugal, Sweden, and Norway.

3. One year prior to the 2004 ISSP survey, Slovenians voted on a divisive referendum about joining NATO (during the Iraq war) and a referendum about joining the EU. In late 2004, Hungarians voted on a popular referendum to grant citizenship to ethnic Hungarians living outside their country.

4. Provincial referendums are more common in Canada, and rules for direct citizen initiatives use exist in one province. State and territorial referendums are also used in Australia. Australia's federal constitution is amended by national referendum.

5. New Zealand also has a longer history of local referendum use.

6. For an analysis of elite support for direct democracy see Bowler, Donovan, and Karp (2002).

7. Respondents were asked, "How interested would you say you personally are in politics?" very interested (4), fairly interested (3), not very interested (2), not at all interested (1).
8. Respondents were asked, "To what extent do you agree or disagree, 'I don't think government cares much what people like me think'?" strongly agree (5), agree (4), neither (3), disagree (2), strongly disagree (1). In a separate battery of questions (ten items later), they were asked, "To what extent do you agree or disagree, 'Most of the time we can't trust people in government to do what is right'?" strongly agree (5), agree (4), neither (3), disagree (2), strongly disagree (1).

9. Respondents were asked, "To what extent do you agree or disagree, 'Political parties do not give voters real policy choices'?" strongly agree (5), agree (4), neither (3), disagree (2), strongly disagree (1).

10. Respondents were asked, "There are different opinions as to what it takes to be a good citizen. As far as you are concerned personally ... how important is it to keep a watch on government?" not at all important (1) to very important (7).

11. Similar results were obtained using ordered logit.

12. The appendix materials are located at http://www.wwu .edu/ donovan/prq07.html.

13. One standard deviation on the 5-point "referendums good" measure is equal to 0.8 . $\beta$ for the estimated effect of "more opportunities" is $.09(.09 \times 6=.54)$.

14. We estimated two-stage/instrumental models and also found no consistent indirect effects of these factors on approval of referendum use.

15. The effect for distrust also holds when additional attitudinal measures are omitted and when models are replicated using ordered logit.

16. One standard deviation on the 7-point "more opportunities" measure is equal to 1.2. $\beta$ for the estimated effect of the 7 point "keep watch" measure is $.20,(.20 \times 6=1.2)$.

17. For example, at the time of the 2003 recall election, 71 percent of Californians supported constitutional provisions for recall (Public Policy Institute of California Poll, August 2003). In 2004, a California/Field Poll found 68 percent saying ballot proposition elections were "good things."

18. As crude examples, consider how narrowly targeted corporate tax credits, nonbid contracts for defense appropriations in Iraq, decisions on the purchase and construction of weapons systems the Pentagon does not request, farm subsidies for large, profitable corporations (e.g., Archer Daniel Midlands Company), sector-specific trade protections, budget "riders" that permit open cyanide-pit gold mining on federal lands, tax exemptions for corporate advertising, and regulations that protect the pharmaceutical and telecommunications industries would fare if decided by a national referendum versus the American legislative process.

19. This 1999 survey of 1,204 Americans was conducted by Communications Center, Inc. for the Center on Policy Attitudes. Frequencies and question wording are available at http://www .policyattitudes.org/questionnaire.html.

\section{References}

Beard, Charles, and Birl Schultz. 1912. Documents on the statewide initiative, referendum and recall. New York: Macmillan.

Bowler, Shaun, and Todd Donovan. Forthcoming. Reasoning about institutional change: Winners, losers, and support for electoral reforms. British Journal of Political Science.

Bowler, Shaun, Todd Donovan, and Jeffrey A. Karp. 2002. When might institutions change? Elite support for direct democracy in three nations. Political Research Quarterly. 55(4):731-754. 
Budge, Ian. 1996. The new challenge of direct democracy. Oxford, UK: Polity.

Burke, Edmund. 1774/1854. Address to the electors of Bristol. In Works of the Right Honourable Edmund Burke, ed. H. Bohn. London: Henry G. Bohn.

Cain, Bruce E., and Kenneth P. Miller. 2001. The populist legacy: Initiatives and the undermining of representative government. In Dangerous democracy? The battle over ballot initiatives in America, ed. Larry J. Sabato, Howard Ernst, and Bruce A. Larson. Lanham, MD: Rowman \& Littlefield.

Craig, Stephen C., Aimie Kreppel, and James G. Kane. 2001. Public opinion and support for direct democracy: A grassroots perspective. In Referendum democracy, ed. M. Mendelsohn and A. Parkin. Houndsmills, UK: Palgrave.

Cronin, Thomas. 1989. Direct democracy: The politics of initiative, referendum, and recall. Cambridge, MA: Harvard University Press.

Dalton, Russell. 1984. Cognitive mobilization and partisan dealignment in advanced industrial democracies. Journal of Politics 46:264-84.

Dalton, Russell, Wilhelm Burklin, and Andrew Drummond. 2001. Public opinion and direct democracy. Journal of Democracy 12:141-53.

Delli Carpini, Michael, and Scott Keeter. 1996. What Americans know about politics and why it matters. New Haven, CT: Yale University Press.

Donovan, Todd and Jeffrey A. Karp. 2006. Popular support for direct democracy. Party Politics 12(5): 671-688.

Dyck, Josh, and Mark Baldassare. 2006. The limits of support for direct democracy. Paper presented at the American Political Science Association meeting, Philadelphia.

Gerber, Elisabeth R. 1999. The populist paradox: Interest group influence and the promise of direct legislation. Princeton, NJ: Princeton University Press.

Haynes, George. 1907. The education of voters. Political Science Quarterly 22:484-97.

Hibbing, John, and Elizabeth Theiss-Morse. 1995. Congress as public enemy. New York: Cambridge University Press.
2001. Process preferences and American politics. American Political Science Review 95:145-54.

- 2002. Stealth democracy: Americans' beliefs about how government should work. New York: Cambridge University Press.

Hicks, John. 1931. The populist revolt. Minneapolis: University of Minnesota Press.

Hofstadter, Richard. 1955. The age of reform: From Bryant to FDR. New York: Knopf.

Inglehart, Ronald. 1977. Silent revolution: Changing values and political styles among Western publics. Princeton, NJ: Princeton University Press.

- 1991. Culture shift in advanced industrial society. Princeton, NJ: Princeton University Press.

Johnson, Claudius. 1944. The adoption of the initiative and referendum in Washington. Pacific Northwest Quarterly 35: 291-304.

LeDuc, Lawrence. 2003. The politics of direct democracy: Referendums in global perspective. Peterborough, Canada: Broadview Press.

Lowi, T. 1969. The end of liberalism: The second republic of the United States. New York: Norton.

Matsusaka, John. 2004. For the many or the few. Chicago: University of Chicago Press.

Norris, Pippa. 1999. Critical citizens: Global support for democratic governance. Oxford: Oxford University Press.

Olson, Mancur. 1964. The logic of collective action: Public goods and the theory of groups. Cambridge, MA: Harvard University Press.

Piott, Steven. 2003. Giving voters a voice: The origins of the initiative and referendum in America. Columbia: University of Missouri Press.

Schattschneider, E. E. 1960. The semi-sovereign people: A realists view of democracy in America. New York: Holt Reinhart Winston.

Schrag, Peter. 2004. Paradise lost: California's experience, America's future. Berkeley: University of California Press.

Sullivan, J. W. 1892. Direct legislation by citizenship through the initiative and referendum. New York: True Nationalist Pub. Co. 